\title{
Comparative Political Studies
}

http://cps.sagepub.com

\section{Democratization and Electoral Reform in the Asia-Pacific Region: Is There an "Asian Model" of Democracy?}

Benjamin Reilly

Comparative Political Studies 2007; 40; 1350 originally published online May 25, 2007;

DOI: $10.1177 / 0010414006299097$

The online version of this article can be found at:

http://cps.sagepub.com/cgi/content/abstract/40/11/1350

\author{
Published by: \\ (3)SAGE Publications \\ http://www.sagepublications.com
}

Additional services and information for Comparative Political Studies can be found at:

Email Alerts: http://cps.sagepub.com/cgi/alerts

Subscriptions: http://cps.sagepub.com/subscriptions

Reprints: http://www.sagepub.com/journalsReprints.nav

Permissions: http://www.sagepub.com/journalsPermissions.nav

Citations (this article cites 13 articles hosted on the

SAGE Journals Online and HighWire Press platforms):

http://cps.sagepub.com/cgi/content/refs/40/11/1350 
Democratization and Electoral Reform in the Asia-Pacific Region

\title{
Is There an "Asian Model" of Democracy?
}

\author{
Benjamin Reilly \\ Australian National University, Canberra
}

\begin{abstract}
During the past two decades, numerous Asia-Pacific states have made transitions to democracy founded on basic political liberties and freely contested elections. A little-noticed consequence of this process has been strikingly congruent reforms to key political institutions such as electoral systems, political parties, and parliaments. Across the region, these reforms have been motivated by common aims of promoting government stability, reducing political fragmentation, and limiting the potential for new entrants to the party system. As a result, similar strategies of institutional design are evident in the increasing prevalence of "mixed-member majoritarian" electoral systems, new political party laws favoring the development of aggregative party systems, and constraints on the enfranchisement of regional or ethnic minorities. Comparing the outcomes of these reforms with those of other world regions, there appears to be an increasing convergence on an identifiable "Asian model" of electoral democracy.
\end{abstract}

Keywords: democracy; electoral systems; political parties; Asia-Pacific

$\mathrm{T}$ The closing decades of the 20th century were years of unprecedented political reform in the Asia-Pacific region. Major transitions from authoritarian rule to democracy began with the popular uprising against the Marcos regime in the Philippines in 1986 and the negotiated transitions from military-backed, single-party governments in Korea and Taiwan in 1987, moving on to the resumption of civilian government in Thailand in 1992, the UN intervention in Cambodia in 1993, the fall of Indonesia's Suharto regime in 1998, and the international rehabilitation of East Timor that culminated in 2001. Despite setbacks such as the Thai coup of September 2006 and violent

Author's Note: Funding from the Australian Research Council supported this research. 
instability in East Timor, the broader pattern is clear: Along with Japan, the region's sole long-standing democracy, more governments are today chosen through competitive and freely contested elections than ever before. This represents a dramatic change in the nature of Asia-Pacific regimes: From what a decade ago was a region dominated by authoritarian rule, there is now a clear trend toward democracy being the accepted means for choosing and changing a country's political leadership.

One aspect of Asian democratization that has received insufficient attention to date has been the impact of institutional reforms to elections, parliaments, and parties via deliberate "political engineering"- the conscious design of political institutions to achieve certain specified objectives. In this article, I argue that many of these reforms have pursued common aims of improving political stability, promoting cohesive party politics, and limiting the enfranchisement of social minorities. For instance, recent electoral reforms in many Asian-Pacific states have sought to promote nationally focused parties and restrict those representing ethnic or regional cleavages. As a result, I argue that there has been a convergence in recent years on an identifiable "Asian model" of democracy characterized by aggregative electoral politics, centrist political competition, and, in some cases, nascent twoparty systems.

It is important at the outset to emphasise just how distinctive this turn toward "majoritarian democracy" (Lijphart, 1984) is in comparative terms. The broader scholarly literature on elections typically assumes an implied (or sometimes explicit) teleological progression toward proportionality when electoral reforms are adopted: Colomer (2004), for instance, argues that there is clear historical tendency toward greater proportionality in electoral system choice globally, whereas Farrell (2001) maintains that "since the early 1990s, the trend has been away from plurality and towards proportional systems" (p. 19). In the Asia-Pacific region, however, this international trend has been reversed: Recent electoral and party reforms in Indonesia, Japan, Korea, Taiwan, Thailand, and the Philippines and in the "semidemocracies" of Cambodia, Malaysia, and Singapore have all resulted in markedly less proportional elections than previously existed.

Asia's increasing convergence on majority-favoring electoral systems runs directly counter to the experience of other democratizing world regions. Latin America's new and restored democracies, for instance, have without exception maintained the party list systems of proportional representation (PR) they inherited from their autocratic predecessors-despite the "difficult combination" of hamstrung executives with fragmented legislatures across the continent (Mainwaring, 1993). In Africa, too, there has been an 
Figure 1

Long-Term Trends in Five World Regions

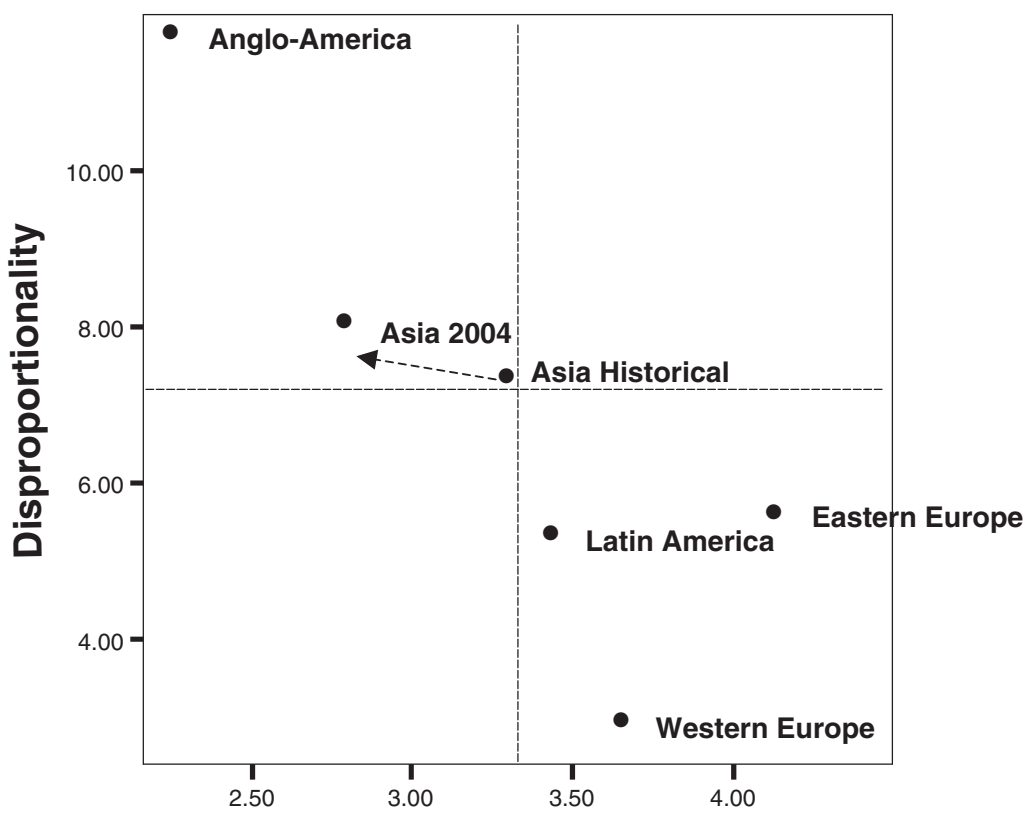

Effective Number of Parties

increasing preference for list PR electoral systems by the region's new democracies - and an equally strong preponderance of one-party-dominant regimes (Bratton \& van de Walle, 1997). Similarly, in Eastern Europe's new democracies, the tendency has been to follow the example of Western Europe and introduce highly proportional electoral systems with strong guarantees for minority rights (Birch, 2003). The trend in the Asia-Pacific region, by contrast, has been in the other direction, toward increasingly majoritarian electoral systems, laws favoring the development of aggregative parties, and constraints on the enfranchisement of ethnic or regional minorities.

To illustrate these different reform trajectories, Figure 1 compares Asia's experience with other regions on two key indicators of electoral and party system performance: the proportionality of electoral outcomes and the effective number of political parties represented in parliament. ${ }^{1}$ Across the Asia-Pacific 
region, electoral disproportionality has historically been high by world standards, at an average level of 7.3 over all democratic elections. ${ }^{2}$ By contrast, in Western Europe, the long-term average is just 2.9-a testament to the preponderance of PR systems across the continent. ${ }^{3}$ Other long-term averages are 5.6 for the postcommunist democracies of Russia and Eastern Europe and 5.3 for Latin America. ${ }^{4}$ As such, the mean disparity between seats and votes in Asia is roughly 50\% higher than in Latin America and Eastern Europe and is almost 3 times that of Western Europe.

Similar patterns are evident in the changing nature of party systems in each region. Asian reformers have often invoked the image of the stable and cohesive two-party systems of the United Kingdom and the United States when advocating political change..$^{5}$ As will be discussed in more detail later in this article, there has been a sharp decline in party fragmentation across the Asia-Pacific region in recent years. Indeed, on the basis of the most recent election outcomes available, a number of Asian states today appear to be in a process of transformation toward a two-party system - and are thus moving ever closer to the long-term democracies of the English-speaking world. This stands in direct contrast to the marked increase in party numbers that has occurred in most Western democracies during the past decade (see Webb, 2002, p. 440).

Figure 1 puts these various facts and figures in comparative context, showing the aggregated disproportionality and party multiplicity scores for Western Europe, Eastern Europe, Latin America, Asia, and a fifth nonregional grouping - the "Anglo-American" democracies of Australasia (Australia and New Zealand) and North America (Canada and the United States). Historically, Asia sits at the midpoint between these groups: On aggregate, electoral outcomes in Asia are more majoritarian than those of Europe and Latin America but less so than in Australasia and North America. However, in recent years, Asia has become significantly more majoritarian on both measures, as shown by the difference in Asia's long-term historical location compared to the end of 2004.

In effect, we appear to be witnessing both a systematic convergence in electoral and party systems across the Asia-Pacific region and the region's systematic divergence from developing democracies in other parts of the world. This dual pattern of convergence and divergence cries out for explanation. What accounts for the increasing institutional isomorphism of the Asia-Pacific region? In what way has the region shifted toward more majoritarian models of democracy? And what might explain the causes behind this striking — and largely unrecognized—development in the region's political evolution? To answer these questions, the remainder of this article traces the 
process of these changes in Asia's "political architecture"- "the complex of rules that make up the constitutional structure and party system" (MacIntyre, 2003, p. 4). It looks first at the specifics of the electoral and party system reforms across the region before examining rival explanations for the emergence of what appears to be a distinctive Asian model of electoral democracy.

\section{Electoral Reform}

The Asian experience of political reform illustrates one of the recurring themes animating the choice of political institutions: the trade-off between efficiency and representation. Classically, representational institutions were considered to facilitate the direct translation of popular preferences and cleavages into the political sphere with as little interference as possible via political parties representing distinct social groups, proportional elections, and low barriers to minority enfranchisement. Together, these institutions should ideally lead to the development of a diverse multiparty system in which all significant social groups and interests are represented. By contrast, "efficient" institutions that deliver clear parliamentary majorities and distinct policy alternatives are more often associated with majoritarian elections and large, "catch-all" political parties that aggregate minority and majority interests alike.

By the terms of this long-running debate, most of the electoral reforms in the Asia-Pacific region in the past decade have clearly come down on the side of efficiency and against representation. This suggests that Asia's newfound preference for majoritarianism is, at heart, an attempt to engineer political stability through the design of democratic institutions. Despite their marked differences in levels of democracy and democratic consolidation, there has been a convergence in reform patterns across the electoral democracies of Japan, South Korea, Taiwan, Indonesia, the Philippines, and Thailand during the past decade. ${ }^{6}$ One example is the increasing enthusiasm for highly disproportional forms of mixed-member majoritarian (MMM) electoral systems, in which most seats are elected from local districts and a much smaller proportion from a party list. ${ }^{7}$ Although mixed systems have become common around the world in the past decade, the Asian variants are quite distinctive, tending to function more like plurality systems than mixed systems in other regions. ${ }^{8}$

Japan, which adopted MMM in 1994, was the most prominent Asian democracy to move to such a system. It was not, however, the first. South 
Korea adopted a highly majoritarian mixed system under military rule in 1963 and should probably be seen as the instigator of this movement, although it was not until 2004 that the allocation of list seats became truly proportional. In the Philippines, provision for a similarly majoritarian mixed model was included in the 1987 constitution, although the first elections under the new system were not held until 1998. Taiwan was the next to introduce the mixed-member option, moving to a single nontransferable vote (SNTV) and PR combination in 1992 and a mixed plurality-PR model in 2005. Thailand and East Timor followed suit in 1997 and 2001, respectively.

Japan's reforms, which remain the best-known example of electoral system change in Asia, were primarily intended to reorient politics away from special interests and promote the development of a two-party system responsive to the interests of the median voter. One effect of Japan's pre1994 SNTV electoral system was to force candidates from the same party to compete with each other for votes-leading directly to personalized and factionalized pork-barrel politics (Sakamoto, 1999). In 1994, after a long debate about the political impacts of its existing electoral arrangements, Japan replaced SNTV with an overtly majoritarian form of mixed system, with three fifths of all seats chosen from single-member districts. As the region's only stable, long-term democracy, the Japanese reforms were stimulated not just by the collapse of public confidence in SNTV but also by a desire among elites to change the conduct of national politics by manipulating the electoral system.

Recent reforms in Taiwan have followed a similar pattern. Taiwan first adopted a mixed system for its legislative Yuan elections in 1992 but continued to use SNTV rules to elect most of the legislature. However, the same problems of personalized and factionalized party politics that had plagued Japan under SNTV also afflicted Taiwan. In 2002, Taiwanese President Chen Shui-bian advanced a similar scheme to the Japanese reforms, proposing that two thirds of the parliament be elected by plurality rules and the remainder from a national list, with electors having a separate vote for each (previously, list seats were simply allocated to parties polling more than $5 \%$ of the total vote in proportion to their vote share at the district level). This new mixed-member plurality-PR model will be used for the first time at parliamentary elections scheduled for 2007 and has brought Taiwan's electoral system design squarely into line with the other Northeast Asian democracies (Lin, 2005).

The South Korean experience of mixed systems has, until recently, represented a third approach to electoral reform. Over the years, Korea has 
experimented with several different combinations of mixed system. Since March 2004, of the Korean National Assembly's 299 seats (restored after a cut to 273 seats for the 2000 elections as a cost-saving response to the Asian economic crisis), 243 are elected from single-member constituencies by a plurality formula, whereas the remaining 56 are chosen from a national constituency by PR. Although previously voters received one ballot only, they now receive separate votes for the district and list seats. As the two components continue to be completely unlinked, this does little to ensure proportionality of outcomes, although it does mean that smaller parties with a dispersed vote share are likely to receive some seats. Prior to 1996, however, list seats were given to parties on the bases of their seat share at district elections, meaning that the national list allocation usually exacerbated any disproportionality arising from the local contests.

Thus, divergent approaches to electoral reform have nonetheless resulted in surprisingly congruent electoral models in these three Northeast Asian cases. A similar conclusion applies to the two longest democracies in Southeast Asia, the Philippines and Thailand. Under its 1987 constitution, the Philippines was the first Asian democracy to adopt a MMM system, with $80 \%$ of the 250 House of Representatives seats elected from singlemember districts via a plurality formula and the remaining $20 \%$ chosen from a national list designed to represent sectoral interests and marginalized groups such as youth, labor, the urban poor, farmers, fishermen, and women. First implemented in 1998, the party list regulations restrict each group's representation to a maximum of three seats. However, as the major parties are barred from competing for list seats, identification of eligible groups has been dogged by problems. In 1998, only 14 of the 52 list seats were filled, as electoral authorities struggled to verify the credentials of elected groups, with similar problems reported in 2001 (May, 2002).

Thailand's 1997 constitutional reforms also introduced a MMM system, with (again) $80 \%$ of the Parliament's 500 seats elected from local constituencies and $20 \%$ from a national party list. This exercise in institutional engineering has created two classes of politicians with radically divergent career incentives: The constituency members of parliament (MPs) represent local districts and are expected to bring development opportunities to them, whereas the list MPs are supposed to concentrate their energies on issues of national, not local, importance. Together with a range of other new institutions (e.g., the new anticorruption commission, ombudsman, and audit offices), these measures were designed not just to combat electoral fraud 
but to radically change the conduct of democratic governance in Thailand. As Allen Hicken (2005) explains,

The drafters hoped that adding a national party list tier and doing away with intra-party competition would encourage voters and candidates to focus more on party policy positions regarding national issues. This in fact began to occur in the 2001 election. For the first time in recent Thai electoral history, political parties, led chiefly by the Thai Rak Thai (TRT) party, put significant effort into developing coordinated party-centred electoral strategies. Parties began to differentiate themselves in terms of their policy platforms and in some cases made those differences an important campaign issue. (p. 107)

The two examples of straight party-list PR in the region, Indonesia and Cambodia, further demonstrate some of the issues driving Asia's electoral reforms. Both countries have seen strong demands for the introduction of a mixed or district-based systems to encourage greater voter-politician linkage and geographic accountability. Following the fall of Suharto in 1998, for instance, Indonesian reformers put forward a plan for a "district plus" mixed-member system very much like those of Northeast Asia." Although unsuccessful, this proposal did encourage electoral experimentation, and Indonesia's 1999 elections were conducted under an unusual and possibly unique hybrid of party list PR with "personal vote" rules in an (unsuccessful) attempt to reward individually popular candidates without moving all the way to a district-based system. At the 2004 elections, a more conventional party-list system was adopted, but with electoral districts capped at a maximum of 12 members. This considerably raised the proportion of votes needed for victory in each district, making it much more difficult for smaller parties to win seats than at previous elections, where districts had been based around entire provinces. The overall effect was to make Indonesia's 2004 electoral arrangements much more majoritarian than they previously were, leading to the elimination of many of the smaller parties present in the previous parliament.

Cambodia, which given the ongoing stranglehold of Hun Sen and the Cambodian People's Party (CPP) on power qualifies as a borderline semidemocracy at best, has also seen calls for the introduction of some kind of district-based or mixed system because of concerns about the lack of accountability in the proportional system inherited from the United Nations transitional administration in 1993. As in Indonesia, recent reforms to Cambodia's list PR electoral system have made it much more majoritarian in practice. Prior to the 1998 elections, for instance, a change in the electoral 
formula saw seats allocated according to the "highest average" method at the provincial level rather than the "largest remainder" nationwide system used in 1993 - a move that discriminated against smaller parties while benefiting the two major parties, the CPP and FUNCINPEC - whereas in response to calls for greater local accountability, a number of district boundaries were adjusted and new districts created, with the result that more than one third of all Cambodian constituencies are now single-member districts. ${ }^{10}$

Asia's newest democracy, East Timor, also used a mixed-member model at its foundation elections in 2001. However, East Timor stands apart from the region's other mixed-member systems, electing most seats from the party list, with highly proportional results. At East Timor's first-ever free elections in August 2001, 75 seats were elected on a nationwide basis by PR, and only 13 seats (one for each district) were elected by plurality. The national liberation party, Fretilin, captured a majority of 55 seats in the 88-member Assembly, winning 43 of the 75 national seats and all of the available district seats. The Assembly then transformed itself into a legislature and passed a new constitution for the country, renamed Timor-Leste. The constitution specifies that elections must be held under PR for a much smaller parliament, so it is likely that future elections will be held under a straight PR system with no district level representation.

Finally, in Southeast Asia's resilient semidemocracies of Malaysia and Singapore, the core features of the electoral system have remained largely unchanged since independence. In both cases, however, a succession of apparently technical changes have tilted the electoral playing field increasingly in favor of the incumbent parties. Malaysia uses a standard Westminster system with plurality elections, but constituency boundaries are gerrymandered to favor the Malay community, and the electoral commission is a compliant servant of the government. As a result, the government has won every election since independence and, with the exception of the 1969 elections, has maintained the two thirds majority required to amend the constitution. At the 2004 elections, the ruling coalition won more than $90 \%$ of seats on $63 \%$ of the vote. The situation is similar in Singapore, which also has never come remotely close to a change of government. There, however, most MPs are elected from multimember "group representation constituencies," each returning between 4 and 6 members, voters choose between competing party lists rather than candidates, and the highest-polling party wins all seats in the district. This "party block" system has hugely benefited Singapore's ruling People's Action Party (PAP), which regularly wins more than $90 \%$ of seats in parliament. At the 2001 elections, for example, the PAP won 82 out of 84 parliamentary seats with $74 \%$ of the vote. 


\section{Table 1}

Electoral Systems Changes in Asia Since 1990

\begin{tabular}{llll}
\hline Country & \multicolumn{1}{c}{$\begin{array}{c}\text { Former Electoral } \\
\text { System }\end{array}$} & \multicolumn{1}{c}{$\begin{array}{c}\text { New Electoral } \\
\text { System }\end{array}$} & Year \\
\hline Cambodia & $\begin{array}{l}\text { Closed list PR (largest } \\
\text { remainder method) }\end{array}$ & $\begin{array}{l}\text { Closed list PR (highest } \\
\text { average method) }\end{array}$ & 1998 \\
East Timor & \multicolumn{1}{c}{ MMM } & 2001 \\
Indonesia & Closed list PR & Open list PR & 2004 \\
Japan & SNTV & MMM & 1994 \\
Philippines & Plurality-block & MMM & 1998 \\
South Korea & Modified plurality & MMM & 1996, \\
Taiwan & Mixed SNTV-PR & MMM & 2003 \\
Thailand & Block vote & MMM & 2005 \\
\hline
\end{tabular}

Note: $\mathrm{PR}=$ proportional representation; $\mathrm{MMM}=$ mixed member majoritarian; $\mathrm{SNTV}=$ single nontransferable vote.

a. The system adopted in South Korea in 1988 delivered list seats to the party that won the most seats in the district contest, ensuring it an overall majority in the assembly. This was changed in 1996 to allocate list seats on the basis of each party's vote (rather than seat) share at the district level. In 2003 a standard mixed-member model, with separate votes for each tier, was adopted.

Table 1 sets out the electoral system changes across region since 1990. As will now be clear, several patterns of electoral reform stand out when analyzing the Asia-Pacific region from a comparative perspective. First, in almost all cases, the region's mixed-member systems are weighted heavily in favor of the majoritarian element of the system and against the proportional part. In South Korea, Thailand, and the Philippines, roughly $20 \%$ of seats are elected from the national list. In Japan, the figure is 38\%; in Taiwan's new system, it is $30 \%$. This is in contrast to the international norm, where well-known examples of mixed systems such as Germany, New Zealand, and Venezuela feature an equal or nearly-equal split between the district and list components. Asian states have also rejected the kind of compensatory mechanisms used in these cases, in which list seats are allocated in such a way as to produce proportional outcomes overall. Rather, every Asian mixed-member system runs the list component of elections in parallel with the district contest, with no linkage between the two.

The limited number of proportional seats in Asia's MMM systems compared to those of other regions can be seen, at least in part, as an 
Table 2

Electoral Disproportionality in Pre- and Postreform Elections

\begin{tabular}{lcccc}
\hline & $\begin{array}{c}\text { Disproportionality } \\
\text { Average All } \\
\text { Elections }\end{array}$ & Years & $\begin{array}{c}\text { Disproportionality } \\
\text { Latest } \\
\text { Election }\end{array}$ & Year \\
\hline Cambodia & 5.42 & $1993-1998$ & 6.10 & 2003 \\
Indonesia & 1.87 & 1999 & 1.50 & 2004 \\
Japan & 4.80 & $1947-2000$ & 7.10 & 2004 \\
Korea & 7.00 & $1988-2000$ & 7.52 & 2004 \\
Taiwan & 3.52 & $1992-2004$ & - & 2007 \\
Thailand $_{\text {The Philippines }}$ & 2.70 & $1992-2001$ & 6.04 & 2001 \\
\hline
\end{tabular}

Source: Croissant (2002, p. 329); author's calculations.

a. Legislative Yuan elections.

b. Party list seats only.

attempt by Asia-Pacific governments to minimize the threat of political fragmentation by restricting the electoral prospects of minor parties and (not incidentally) promoting the interests of incumbents. Although smaller parties may legitimately hope to gain some representation from the party list seats, overall levels of proportionality are in most cases more like those of a plurality system than a PR one due to the combined effect of the lack of any compensatory mechanism and the relatively small number of list seats on offer.

To illustrate the impacts of such overtly majoritarian structures, Table 2 shows the changing disproportionality levels for prereform and postreform elections in Japan, Cambodia, Korea, Taiwan, Thailand, Indonesia, and the Philippines. In almost all cases, disproportionality rates after electoral reforms had been introduced were considerably higher than previous levels. In Thailand and Japan, for example, the first elections held under the new MMM systems resulted in disproportionality levels almost twice those of previous elections. As Croissant (2002) notes,

The change in vote-seat deviation in the wake of electoral reforms is remarkable.... [In Thailand] disproportionality rose significantly after components of the PR system were introduced. The same is true for the Philippines's partylist system, used for the first time ever in 1998 and again in 2001. (p. 329)

Cambodia also saw a fall in proportionality because of the change of electoral formula and the increased use of single-member districts. Only Indonesia, 
where proportionality marginally increased between 1999 to 2004, bucks this trend-somewhat surprisingly given the marked reduction in average district magnitude there.

\section{Political Parties}

In addition to revising their electoral systems, reformers in a number of transitional Asia-Pacific states have also tried to engineer the development of their nascent party systems via new rules governing the formation, registration, and campaigning of political parties. ${ }^{11}$ Party-formation rules have so far received scant attention from scholars but are an increasingly popular means of political engineering in many new democracies. ${ }^{12}$ Three distinct strategies of such "party engineering" can be identified in Asia: those that try to promote the development of a national party systems and hamper the growth of regional, local, or secessionist parties; those that attempt to control, influence, or restrict the number of parties; and finally those that seek to strengthen party organizations by building stable party systems from the top down.

The most direct means of fostering broad-based political parties with a truly nationwide policy focus is to ensure that parties are elected on a national basis and thus need to draw support from different regions of the country and segments of the electorate. However, this is easier said than done. In presidential systems such as Indonesia, Korea, Taiwan, and the Philippines and in "semipresidential" East Timor and Taiwan, candidates for president are indeed nationally elected and thus need to appeal to a nationwide constituency. In the Philippines, senators are also elected on an at-large basis from one national constituency, making them more responsive to geographically dispersed interests and less focused on particularistic policy than their counterparts in the House of Representatives (Eaton, 2002). However, the constraints of geography, the desire for accountability, and the practicalities of election system design make direct national election of all seats impractical in most countries. More indirect approaches to the promotion of nationally oriented politics include requirements in Thailand that parties maintain membership and branch networks in each of the country's four main regions, which must also be "equitably represented" at Senate elections, ${ }^{13}$ and similar provisions in the Philippines that require new parties to establish regional offices in at least 9 of the country's 16 regions and to gain support in more than half of the cities and provinces where their candidates run (Hartmann, Hassall, \& Santos, 2001, p. 195). 
The country that has taken the engineering of political parties the furthest, however, has been Indonesia. Under Suharto's New Order regime, only three officially sanctioned and controlled "national" parties were allowed. Following the regime's collapse in 1998, more than 100 new parties emerged within the space of a few months, many with extremely limited support bases, provoking widespread elite concern that Indonesia's emerging party system would be too fragmented for democracy to work effectively (Tan, 2002). At the same time, there were overriding concerns, particularly since the breakaway of East Timor in 1999, of secessionism in outer provinces such as Aceh and Papua and a very real fear of the country breaking up under separatist pressures. The development of a national party system was thus seen as an essential step in countering secessionist sentiment and building a viable democracy.

To achieve these twin goals - promoting national parties while resisting separatist ones-Indonesia's political reformers introduced a complex bundle of incentives and constraints on party system development. On one hand, all parties were required to demonstrate that they had a national support base as a precondition to contest the transitional 1999 elections. The new rules required each party to establish branches in at least one third of Indonesia's (then) 27 provinces and in more than half the districts or municipalities within these provinces. As King (2003) notes, "Where previously the number of election contestants was stipulated by law, permitting only three, now they were limited on the basis of insufficient geographical coverage and depth of penetration of their organizations" (p. 51). This bias was so strong that regional parties were even banned from competing in elections to the regional assemblies, where again only national-level parties were permitted.

These new rules had an immediate impact. Of the 141 parties that applied to contest the 1999 elections, only 48 were approved to run, and of these, only 5 gained significant representation at the election itself: the Indonesian Democratic Party led by then-president Megawati Sukarnoputri; Golkar, the party machine created by Suharto; and three Islamic parties, the National Mandate Party, the Development Unity Party, and the National Awakening Party of Megawati's predecessor, Abdurrahman Wahid (Suryadinata, 2002, pp. 90-92). For the 2004 elections, the party laws went even further than in 1999. New parties had to establish branches in two thirds of all provinces and in two thirds of the municipalities within those provinces. Each municipal party unit also had to demonstrate that it had at least 1,000 members (or at least one one-thousandth of the population in smaller regions). This led to a further consolidation of the party system, with only 24 parties qualifying 
to contest the 2004 elections: the 6 top parties from 1999 plus 18 new or merged parties that met the cross-regional membership requirements.

However, unlike 1999, many of these parties proved to be electorally viable. Although the 1999 assembly was dominated by the "big five," the 2004 parliament featured the "big seven": the five main parties from 1999 plus two new entrants: the Justice and Welfare Party and the Democrat Party of Indonesia's current president, Susilo Bambang Yudhoyono. Importantly, most of these large parties were able to command significant voter support across western, central, and eastern Indonesia-no small achievement given Indonesia's modern history and the dangers of acute fragmentation that it faces. Although King (2003) argues that Indonesia's post-Suharto elections have broadly replicated the societal and religious cleavages of the previous democratic election in 1955, the fact that most of the major parties at the 2004 election commanded a degree of cross-regional supportin part, it appears, because of the new party-formation rules-is actually a significant contrast.

Indonesia also held its first direct national election for president and vice president in 2004. Like the new party laws, the presidential voting system was designed to ensure that only broadly supported, nationally oriented candidates were likely to be elected. Only parties winning at least $5 \%$ of the vote or 3\% of seats in the parliamentary elections were allowed to nominate candidates, sidelining smaller parties. Presidential and vice presidential candidates had to run together as teams; as a result, most major parties chose a combination of Javanese and outer islands candidates to maximize their appeal. The election was conducted over two rounds of voting; to avoid a runoff, first-round winners had to gain more than $50 \%$ of all votes and at least $20 \%$ in half of all provinces. ${ }^{14}$ Again, the aim was to ensure that winning candidates commanded not only majority support overall but broad cross-regional support as well. In the event, no candidate won a first-round majority, so the distribution requirements were not directly tested.

Other Asia-Pacific states have also attempted to influence the development of their political party systems. Thailand's ambitious 1997 constitutional reforms, for example, were designed to restructure its party system by promoting political aggregation and reducing party fragmentation. In addition to the cross-regional membership requirements, new parties must show they have at least 5,000 members within 6 months of being registered; parties that fail to meet the membership criteria face the threat of being deregistered (A. Hicken, personal communication, November 15, 2004). In Korea, similarly, local party organizations must be located in a specified number of local electoral districts across the country, and district party organizations are required to have a minimum membership. Choi (1997) 
argues that "although this statutory requirement favors big parties above minor parties, it also contributes to political stability by preventing extreme pluralism (that is, very small parties with limited public support) from emerging" (p. 83). Such schemes thus echo the Indonesian reforms, even though they are aimed at restricting political fragmentation more generally rather than separatist parties in particular.

A third approach to party engineering in the Asia-Pacific region has been to try to strengthen internal party organizations. In both Indonesia and Thailand, for example, all lower house candidates must represent a political party and are not permitted to stand as independents. In Indonesia, the systemic and educative role of parties is also emphasized in the new legislation governing party registration, and party leaders are given significant power in terms of candidate selection and replacement. In 1999, public funding was also introduced (King, 2003, p. 52). In Korea, both main parties instituted American-style primary elections in 2001 in an attempt to transform themselves into more open organizations with a mass membership base. The new party primaries had an immediate impact with the nomination of Roh Moon-Hyun, a relative outsider, as the ruling Millennium Democratic Party's candidate for president. Roh's rapid rise in popularity, particularly among younger voters, and his subsequent victory at the 2002 presidential elections greatly strengthened the new internal party governance measures and spurred the rival Grand National Party to announce similar reforms. Whether these changes will be sufficient to transform Korea's weak, regionalized, and personality-dominated party system into one based around true mass parties with a national reach, however, remains to be seen (Im, 2004, p. 187).

Other approaches seek to strengthen parties' internal control over their members to maintain greater organizational cohesiveness and stability and restrict the capacity of parliamentarians to change parties. These measures aim to make it difficult or impossible for a politician elected under one party label to switch to another party in exchange for a ministerial appointment or similar inducement. In Thailand, for example, the 1997 constitution mandates that candidates must be members of a political party for at least 90 days prior to an election-double the standard interval between the end of a parliamentary term and the election that follows. As a result, politicians who switch parties to help bring down a government usually cannot legally contest the forthcoming election (Hicken, 2003).

A final means of reducing the number of parties has been to use technical electoral barriers such as vote thresholds, which prevent the election of smaller parties to parliament. In both Thailand and Taiwan, for example, parties competing for party-list seats must attain at least $5 \%$ of the vote, a 
provision that discriminates against minor parties. In Korea, the rules are more complex: Although a $3 \%$ threshold also applies to the party list component, this is disregarded for parties that win at least five district seats. The Philippines also applies a $2 \%$ threshold to its party lists seats. Indonesia's new party laws attempt to restrict the number of parties by introducing systemic pressures for party amalgamation. Following the 1999 election, political parties that failed to gain more than $2 \%$ of seats in the lower house of parliament, or at least 3\% of seats in regional assemblies, had to merge with other parties to contest future elections. Only six parties cleared this threshold, resulting in a number of parties amalgamating prior to the 2004 elections. Again, the overall impact is to discriminate against smaller parties and in favor of large ones, particularly incumbents.

How have these various attempts to limit party fragmentation worked in practice? In some cases, such as in Thailand, the impact was dramatic. There, the effective number of parties declined by almost $50 \%$, from an average of 7.2 in the 10-year period from 1986 to 1996 to 3.8 at the first postreform elections in April 2001. In Indonesia, the absolute number of parties dropped from 48 in 1999 to 24 at the 2004 poll—again, a 50\% decline during one parliamentary term-although the effective number of parliamentary parties actually rose, from 5.4 in 1999 to 8.3 in 2004, as votes that went to smaller parties in 1999 were more evenly spread across the large parties. In Japan, the MMM electoral reforms have also led to a steady drop in effective party numbers-from an average of 3.7 effective parties during the postwar period to an average of 2.9 parties for the three elections since the 1994 reformsa $20 \%$ decline during 9 years. ${ }^{15}$

Compare this with the experience of the Philippines. The Philippines's 1987 constitution was also based on the desire for a more predictable and consolidated political system, but it included no reductive constraints on party fragmentation. There, party numbers have steadily increased since the return to democracy in 1986, especially compared to the experience of the pre-Marcos democratic period from 1946 to 1969 (Hicken, 2003). One reason for this was the introduction of term limits for legislators and the president in the 1986 constitution. A response to the disastrous Marcos period of authoritarian rule, term limits were aimed at undercutting the entrenched rule of wealthy family dynasties that have long been a feature of Filipino politics but had the unintended effect of weakening the power of incumbents, lowering barriers for new entrants, and drastically undermining incentives for presidents and legislators to invest in the hard work of party building. The result has been an increase in party fragmentation in the Philippines in the post-1986 period to more than double the level that applied in the 1946 to 1969 democratic era—an ironic outcome, as an underlying aim of the 1986 
constitution was to improve political stability (Choi, 2001). Following her election in May 2004, Filipino President Gloria Arroyo outlined new plans to strengthen the party system by implementing constitutional restrictions on party switching and providing public funding to major parties while endorsing proposals for a shift to a parliamentary and federal system of government.

These various attempts to engineer the emerging party system in the Philippines, Thailand, and Indonesia are particularly significant in the context of each country's troubled democratic history. Thailand has a long history of fragmented party politics leading to ineffectual coalition governments and frequent coups, most recently the 2006 military takeover that removed Prime Minister Thaksin Shinawatra from power. Similarly, many Indonesians blame the fragmented and polarized party system of the 1950s for the failure of democracy that occurred then and are determined not to see it happen again. Opinion surveys in Indonesia have found a strong preference for a moderate multiparty system rather than a fragmented one (Tan, 2002, pp. 501-502). Building a consolidated party system has thus been seen in both countries as an essential step in building a consolidated democracy.

However, such overt interventions in political party development entail costs as well as benefits. Restrictions on party fragmentation can easily become restrictions on democracy itself. A lighter touch may well be more desirable for new democracies. In Indonesia, for example, the 2004 party laws place such high thresholds on party support that they represent a clear restriction on new entrants into the political system. Similarly, the Thai reforms, while sharply reducing fragmentation, also excessively centralized government power in Thaksin's hands - undermining democratic consolidation and providing a clear pretext for the September 2006 coup.

\section{Conclusion: An Asian Model?}

In the early 1990s, the rapid development of East Asian economies led to claims for the superiority of "Asian-style democracy" as an alternative to the Western liberal model. Two long-serving Southeast Asian prime ministersLee Kwan Yew of Singapore and Mahathir Mohamad of Malaysia-were the most enthusiastic propagators of this claim for a distinct Asian style of government based on hegemonic, one-party rule underpinned by communal values of family solidarity and personal discipline, which they contrasted to the perceived economic and moral decay of the West in general and the United States in particular ("East Beats West," 1995; Zakaria, 1994). 
The evidence of this article suggests that there is indeed an Asian model of democracy — but one that, in something of a grand irony, is in some ways moving closer to the Anglo-American model of two-party democracy. In Japan, for example, party numbers have fallen since the introduction of the 1994 electoral reforms to just 2.4 effective parties at the November 2003 elections-a process that suggests "an evolution towards a two-party system" (Reed, 2002, p. 260). In Taiwan, the 2004 elections saw the two main parties, the "pan-blue" KMT and the "pan-green" DPP, garner more than $95 \%$ of all seats, prompting some observers to claim that Taiwan's democracy was "moving toward a twoparty system more quickly than expected" (Copper, 2004, p. 12).

In Thailand, the 1997 constitutional reforms and the rise of the TRT comprehensively altered the once-fragmented Thai party system to the point where it effectively became a one-party dominant system, with just 1.65 effective parties after the February 2005 elections (won by the TRT in a landslide of 376 seats, with the Democrat Party the only significant opposition) - an outcome interpreted by some commentators as proof of Thailand's "drift towards a two-party system" ("Why They All," 2005, p. 26). In Korea, the long-term trend also appears to be toward party consolidation, with effective party numbers falling from an average of 2.95 between 1988 and 2000 to just 2.36 following the 2004 election. In Cambodia, too, party fragmentation has fallen over time, to 2.29 in 2004 . Although none of these cases could be called a two-party system, recent changes in the party system have clearly been in the direction of greater consolidation. ${ }^{16}$

The main exceptions to this trend in the Asia-Pacific region are Indonesia and the Philippines - both of which have witnessed an increase in party fragmentation following the political openings that accompanied the fall of the Suharto and Marcos regimes, respectively. The high levels of social diversity of these two countries, combined with the fact that both have only recently emerged from extended authoritarian rule in which the composition and number of parties were controlled from above, is one explanation for this pattern. Suharto's forced amalgamation of all Indonesian parties into three "official" political parties in the mid-1970s was one reason for the mushrooming of new parties when restrictions were lifted in 1998. In the Philippines, similarly, multiparty politics was a central objective of the post-Marcos 1987 constitution's stated aim of promoting party multiplicity, in contrast to the one- or two-party systems of the past. These exceptions aside, the apparent movement toward majoritarian politics in Asia provides a striking affirmation of the way the political systems of the Asia-Pacific region have evolved in recent years.

How do we explain this historical shift and the broader convergence on MMM electoral models and aggregative parties across the region? At this 
stage, any causal explanations must remain speculative. But there are several hypotheses worth exploring. One was alluded to above: the "Asian values" thesis, which holds that the search for a stable, balanced, and harmonious political order has been a recurring theme in Asian political thought for centuries (Bell, 2000). Under this interpretation, the recent turn toward majoritarian politics in the Asia-Pacific region may herald a drift away from democratic values toward a new form of illiberal democracy-in effect, a return to Asia's long experience with dictatorial, autocratic, monarchistic, or other forms of nondemocratic rule. Although the Thai coup is a clear backward step, the broader upward trajectory of democracy across the region belies this interpretation, the "Asian values" claimants were dealt a major blow by the 1997 economic crisis that laid bare the structural weaknesses of the region's political and economic systems.

Another possible explanation is that the political changes that have taken place across the region are, at their heart, an all-too-familiar case of selfinterested politicians seeking to ensure their electoral prospects by rejigging political rules in their favor. There is no doubt that recent electoral reforms in Asia-Pacific states have helped ruling incumbents insulate themselves from potential challengers by restricting minority representation and promoting the interests of large parties. As a result, in contrast to democratizing states in many other world regions, the Asia-Pacific region's new democracies have become more efficient but less representative in recent years. But the self-interested politicians argument fails to explain why and how Asia's democratically elected leaders have been able to push through these kinds of incumbent-benefiting reforms when their counterparts in Europe and Latin America have not.

A third possible explanation is that Asia's distinctive democratic development in recent years heralds a genuinely new form of political architecture in the region-one based on a historic compromise between mass constituents who have embraced the need for more programmatic and effective parties and elite politicians who favor restrictions on political fragmentation and the suppression of ethnic or regional movements. ${ }^{17}$ Certainly, the reform trajectory of states such as Thailand, Indonesia, and even Japan gives some credence to the idea that institutional change is the outcome of successive trade-offs between demands for reform from below with the perennial interests of incumbents from above. Although compelling, however, the mass-elite compromise argument again fails to explain why the outcome of democratization has played out this way in Asia but not elsewhere.

More definite causal explanations for the Asia-Pacific region's distinctive pattern of democratic development will therefore have to wait. In the meantime, 
it is worth reiterating the key empirical finding of this article: Convergent patterns of political reform across the region have seen the development of what appears to be an identifiable Asian approach to the design of democratic institutions, making the outcomes of democratization in the Asia-Pacific region quite distinctive by world standards. The increasing shift toward distinctively majoritarian mixed-member electoral systems and embryonic twoparty systems in what were previously either one-party autocracies or unstable multiparty democracies is perhaps the most compelling evidence for this emerging Asian model of electoral democracy.

\section{Notes}

1. There are a number of ways to measure electoral disproportionality, but the simplest is to calculate the average disparity between the proportion of votes and seats won by the two largest parties, an approach used in this article (see Lijphart, 1984, p. 163). The effective number of parliamentary parties is the inverse of the sum of the squared proportions of each party's seats (Laakso \& Taagepera, 1979).

2. Calculated from data presented in Croissant (2002, p. 329), updated by the author.

3. Calculated from data presented in Lijphart (1984, p. 161).

4. Calculated from data presented in Birch (2003, pp. 111-114) and Payne, Zovatto, Flórez, and Zavala (2002, p. 108).

5. In Japan, for example, former Liberal Democratic Party Secretary General Ichiro Ozawa vigorously promoted electoral reform, arguing that a two-party system was necessary for Japan's long-term survival (see Sakamoto, 1999, pp. 431-432).

6. For two excellent recent surveys of Asian electoral systems, see Croissant, Bruns, and John (2002) and Hicken and Kasuya (2003). The most comprehensive collection on the subject is Nohlen, Grotz, and Hartmann (2001).

7. This is the term used in the best single collection on mixed-member electoral systems (Shugart \& Wattenburg, 2001). However, they define mixed-member majoritarian (MMM) as any unlinked mixed-member system regardless of its distribution of seats between districts and list. In Asia, this would include not just Japan, Korea, Taiwan, Thailand, and the Philippines but also East Timor, in which $85 \%$ of all seats are proportionately chosen. This makes little sense; I therefore restrict the term $M M M$ to refer to unlinked systems that elect a majority of seats from local districts.

8. For more on mixed-member systems, see Reynolds, Reilly, and Ellis (2005).

9. Under the proposal, $76 \%$ of seats would have been allocated to single-member districts, with the remaining $24 \%$ elected by proportional representation (see King, 2003, p. 60).

10. At the time of writing, 8 of Cambodia's 23 districts were single member, up from 6 in 1993.

11. For more on this, see Reilly (2003).

12. For examinations of the political impact of party-formation rules, see Birnir (2004) and Reilly (2006).

13. Constitution, Art. 99, and Electoral Law, Art. 35.

14. The second round of voting entails a straight runoff between the two leading candidate teams, with no distribution requirement. 
15. My thanks to Allen Hicken and Yusaku Horiuchi for the Thai and Japanese data, respectively.

16. Author's calculations.

17. My thanks to one of this journal's anonymous referees for suggesting this interpretation.

\section{References}

Bell, D. (2000). East meets West: Human rights and democracy in East Asia. Princeton, NJ: Princeton University Press.

Birch, S. (2003). Electoral systems and political transformation in post-communist Europe. Hampshire, UK: Palgrave Macmillan.

Birnir, J. (2004). Stabilizing party systems and excluding segments of society? The effects of formation costs on new party foundation in Latin America. Studies in Comparative International Development, 39(3), 3-27.

Bratton, M., \& van de Walle, N. (1997). Democratic experiments in Africa. Cambridge, UK: Cambridge University Press.

Choi, D. (1997). The choosing of representatives in Korea. In G. Hassall \& C. Saunders (Eds.), The people's representatives: Electoral systems in the Asia-Pacific region (pp. 77-86). Sydney, Australia: Allen \& Unwin.

Choi, J. (2001). Philippine democracies old and new: Elections, term limits, and party systems. Asian Survey, 41(3), 488-501.

Colomer, J. (2004). The strategy and history of electoral system choice. In J. Colomer (Ed.), Handbook of electoral system choice (pp. 3-79). Hampshire, UK: Palgrave Macmillan.

Copper, J. (2004). Taiwan's democracy takes a new step. Far Eastern Economic Review, 168(1), 12-14.

Croissant, A. (2002). Electoral politics in Southeast and East Asia: A comparative perspective. In A. Croissant, G. Bruns, \& M. John (Eds.), Electoral politics in Southeast and East Asia (pp. 321-362). Singapore: Friedrich Ebert Stiftung.

Croissant, A., Bruns, G., \& John, M. (Eds.). (2002). Electoral politics in Southeast and East Asia. Singapore: Friedrich Ebert Stiftung.

East beats West. (1995, 8 September). Asiaweek, p. 41.

Eaton, K. (2002). Politicians and economic reform in new democracies: Argentina and the Philippines in the 1990s. University Park: State University of Pennsylvania Press.

Farrell, D. (2001). Electoral systems: A comparative introduction. Hampshire, UK: Palgrave.

Hartmann, C., Hassall, G., \& Santos, S. (2001). Philippines. In D. Nohlen, F. Grotz, \& C. Hartmann (Eds.), Elections in Asia and the Pacific: A data handbook (pp. 195-238). Oxford, UK: Oxford University Press.

Hicken, A. (2003, August). From province to parliament: Party aggregation in developing democracies. Paper presented to the Annual Meeting of the American Political Science Association, Philadelphia.

Hicken, A. (2005). Thailand. In A. Reynolds, B. Reilly, \& A. Ellis (Eds.), Electoral system design: The new International IDEA handbook (pp. 107-108). Stockholm: International Institute for Democracy and Electoral Assistance.

Hicken, A., \& Kasuya, Y. (2003). A guide to the constitutional structures and electoral systems of East, South and Southeast Asia. Electoral Studies, 22, 121-151.

Im, H. (2004). Faltering democratic consolidation in South Korea: Democracy at the end of the “Three Kims" era. Democratization, 11(5), 179-198. 
King, D. (2003). Half-hearted reform: Electoral institutions and the struggle for democracy in Indonesia. Westport, CT: Praeger.

Laakso, M., \& Taagepera, R. (1979). Effective number of parties: A measure with application to Western Europe. Comparative Political Studies, 12, 3-27.

Lijphart, A. (1984). Democracies: Patterns of majoritarian and consensus government in twenty-one countries. New Haven, CT: Yale University Press.

Lin, J. (2005). Party realignment and the demise of SNTV in East Asia. Unpublished manuscript, Institute of Political Science, Academia Sinica, Taiwan.

MacIntyre, A. (2003). The power of institutions: Political architecture and governance. Ithaca, NY: Cornell University Press.

Mainwaring, S. (1993). Presidentialism, multipartism, and democracy: The difficult combination. Comparative Political Studies, 26(2), 198-228.

May, R. J. (2002). Elections in the Philippines, May 2001. Electoral Studies, 21(4), 673-680.

Nohlen, D., Grotz, F., \& Hartmann, C. (Eds.). (2001). Elections in Asia and the Pacific: A data handbook. Oxford, UK: Oxford University Press.

Payne, M., Zovatto, D., Flórez, F., \& Zavala, A. (2002). Democracies in development: Politics and reform in Latin America. Washington, DC: Inter-American Development Bank and International Institute for Democracy and Electoral Assistance.

Reed, S. (2002). Evaluating political reform in Japan: A mid-term report. Japanese Journal of Political Science, 3(2), 243-263.

Reilly, B. (2003). Political parties and political engineering in the Asia-Pacific region. Asia Pacific Issues: Analysis from the East-West Center, 71, 1-8.

Reilly, B. (2006). Political engineering and party politics in conflict-prone societies. Democratization, 13(5), 811-827.

Reynolds, A., Reilly, B., \& Ellis, A. (Eds.). (2005). Electoral system design: The new International IDEA handbook. Stockholm: International Institute for Democracy and Electoral Assistance.

Sakamoto, T. (1999). Explaining electoral reform: Japan versus Italy and New Zealand. Party Politics, 5(4), 419-438.

Shugart, M., \& Wattenburg, M. (Eds.). (2001). Mixed-member electoral systems: The best of both worlds? New York: Oxford University Press.

Suryadinata, L. (2002). Elections and politics in Indonesia. Singapore: Institute of Southeast Asian Studies.

Tan, P. (2002). Anti-party reaction in Indonesia: Causes and implications. Contemporary Southeast Asia, 24(3), 484-508.

Webb, P. (2002). Conclusion: Political parties and democratic control in advanced industrial societies. In P. Webb, D. Farrell, \& I. Holliday (Eds.), Political parties in advanced industrial democracies (pp. 438-460). Oxford, UK: Oxford University Press.

Why they all love Thaksin. (2005, February 12). The Economist, p. 26.

Zakaria, F. (1994). Culture is destiny: A conversation with Lee Kwan Yew. Foreign Affairs, 73(2), 109-126.

Benjamin Reilly is director of the Centre for Democratic Institutions at the Australian National University, Canberra. He is the author of six books on aspects of democracy, electoral systems, and conflict management, most recently Democracy and Diversity: Political Engineering in the Asia-Pacific (Oxford University Press, 2006). 